\title{
Influence of floatation technique on seed and seedling characters in davana (Artemisia pallens)
}

\author{
M. JAYANTHI* AND A.VIJAYAKUMAR \\ Department of Seed Science and Technology, Tamil Nadu Agricultural University, COIMBATORE (T.N.) INDIA \\ (Email : mjayanthi8@gmail.com)
}

\begin{abstract}
Davana (Artemisia pallens) is an important high valued annual medicinal and aromatic herb of India belonging to the family Asteraceae. India has a monopoly in production and export trade of davana oil and India stands $3^{\text {rd }}$ in essential oil production in the world. This study was conducted at the Department of Seed Science and Technology, Tamil Nadu Agricultural University, Coimbatore to upgrade the seed quality of davana seeds. The seeds were subjected to the following seed quality assessment. The observation made on seed recovery (\%), 1000 seed weight (mg), germination per cent, seedling length $(\mathrm{cm})$, dry matter production and vigour index. The results revealed that davana seeds upgraded with petroleum ether was found to improve the seed quality parameters viz., 1000 seed weight $(120 \mathrm{mg})$, germination $(71 \%)$ and vigour index (170.0).
\end{abstract}

Key Words : Davana, Seed quality, Upgrading, Seed recovery per cent, Germination per cent, Seedling length, Drymatter production, Vigour index

View Point Article : Jayanthi, M and Vijayakumar, A. (2016). Influence of floatation technique on seed and seedling characters in davana (Artemisia pallens). Internat. J. agric. Sci., 12 (2) : 230-233, DOI:10.15740/HAS/IJAS/12.2/230-233.

Article History : Received : 21.01.2016; Revised : 17.02.2016; Accepted : 20.04.2016 